\title{
Analysis of the photosynthetic apparatus in transgenic tobacco plants with altered endogenous cytokinin content: a proteomic study
}

\author{
Anne Cortleven ${ }^{1}$, Jean-Paul Noben ${ }^{2}$ and Roland Valcke ${ }^{1^{*}}$
}

\begin{abstract}
Background: Cytokinin is a plant hormone that plays a crucial role in several processes of plant growth and development. In recent years, major breakthroughs have been achieved in the elucidation of the metabolism, the signal perception and transduction, as well as the biological functions of cytokinin. An important activity of cytokinin is the involvement in chloroplast development and function. Although this biological function has already been known for 50 years, the exact mechanisms remain elusive.

Results: To elucidate the effects of altered endogenous cytokinin content on the structure and function of the chloroplasts, chloroplast subfractions (stroma and thylakoids) from transgenic Pssu-ipt and 35S:CKX1 tobacco (Nicotiana tabacum) plants with, respectively, elevated and reduced endogenous cytokinin content were analysed using two different 2-DE approaches. Firstly, thykaloids were analysed by blue-native polyacrylamide gel electrophoresis followed by SDS-PAGE (BN/SDS-PAGE). Image analysis of the gel spot pattern thus obtained from thylakoids showed no substantial differences between wild-type and transgenic tobacco plants. Secondly, a quantitative DIGE analysis of CHAPS soluble proteins derived from chloroplast subfractions indicated significant gel spot abundance differences in the stroma fraction. Upon identification by MALDI-TOF/TOF mass spectrometry, these proteins could be assigned to the Calvin-Benson cycle and photoprotective mechanisms.

Conclusion: Taken together, presented proteomic data reveal that the constitutively altered cytokinin status of transgenic plants does not result in any qualitative changes in either stroma proteins or protein complexes of thylakoid membranes of fully developed chloroplasts, while few but significant quantitative differences are observed in stroma proteins.
\end{abstract}

\section{Background}

Cytokinin is a class of plant hormones that affects multiple aspects of plant growth and development including cell division, vascular development, sink/source relations, apical dominance and leaf senescence [1,2]. Most steps of the cytokinin synthesis and breakdown [3], as well as its perception by membrane-located histidine kinases and transduction of the signal through a twocomponent signalling system, have been elucidated [4]. In addition, several activities of the hormone in regulating intrinsic developmental pathways and responses to environmental changes have been discovered [5].

\footnotetext{
* Correspondence: roland.valcke@uhasselt.be

'Laboratory of Molecular and Physical Plant Physiology, Faculty of Sciences, Hasselt University, Diepenbeek, Belgium

Full list of author information is available at the end of the article
}

However, an important activity of cytokinin, that was found soon after the discovery of cytokinin as a plant growth regulator, namely the involvement of cytokinin in chloroplast development, is poorly understood.

Several in vitro studies demonstrated that cytokinin can delay the yellowing of leaves (for review see [6]). Later, Stetler and Laetsch [7] reported a stimulation of chloroplast differentiation upon kinetin treatment. Parthier [8] also showed that exogenously applied cytokinin stimulates deetiolation, i.e. the transition of etioplasts into chloroplasts in detached leaves. Other studies showed that the biogenesis of chloroplasts is regulated by cytokinin providing components of the electron transport chain, structural and functional proteins and enzymes for the formation of the chloroplast stroma in vivo, and increases the life span of chloroplasts [1,9-12].

\section{C) Biomed Central}


Cytokinin also affects pigment accumulation and the rate of photosynthesis [13-16]. Besides the effects on chloroplast structure and function itself, Okazaki et al. [17] revealed that cytokinin increases the chloroplast division rate. Chloroplasts themselves contain a broad set of cytokinins, including free bases, ribosides and Nglucosides [18]. Moreover, four cytokinin biosynthetic proteins (AtIPT1, AtIPT3, AtIPT5, and AtIPT8) are targeted to plastids [19].

Since the discovery of the effect of cytokinin on chloroplast development, most analyses have been performed on the effect of cytokinin on the transcript level [20-24]. Kusnetsov et al. [14] mentioned the stimulating effect of cytokinin on chloroplast proteins in Lupinus luteus cotyledons without notable effects on steady-state mRNA levels.

Expression profiling of cytokinin action in Arabidopsis or barley have been profoundly studied using endogenous altered cytokinin content or exogenous application of cytokinins. Hoth et al. [20] endogenously elevated the cytokinin content in Arabidopsis and revealed several targets of cytokinin responsive genes, especially genes involved in the cytokinin signal transduction pathway. Both Rashotte et al. [21] and Brenner et al. [22] applied exogenously cytokinins to Arabidopsis and found that the cytokinin-upregulated genes included, for example, transcription factors and cytokinin signalling proteins. In addition, Brenner et al. [22] showed that some genes involved in chloroplast development and function were upregulated. Further direct effects of the exogenous application of cytokinins on the activation of transcription of chloroplast genes in barley have been described by Zubo et al. [23,24]. They demonstrated that some genes (e.g. PETD, ATPA, RRN16) are highly responsive to cytokinin treatment, while other genes remain unaffected. Only a few proteomic studies have investigated the effect of cytokinin on chloroplasts. Lochmanova et al. [25] described the effects of cytokinin-induced photomorphogenesis in dark-grown Arabidopsis on the protein level. They reported that even a modest increase in the endogenous cytokinin level $(<2$-fold increase) resulted in an upregulation of 37 proteins, mostly related to chloroplast biogenesis. More recently, Cerny et al. [26] described the early cytokinin response proteins and phosphoproteins in 7-day-old Arabidopsis thaliana plants. They not only confirmed the already known functions of cytokinin, but they also revealed that most differently regulated phosphoproteins are located in chloroplasts. Therefore, they suggested the presence of a not yet known signalling chain located in the chloroplast responsible for the cytokinin action.

In the past, effects of cytokinins were determined by applying cytokinins exogenously to the plants. This method is accompanied by many negative effects. High, non-physiological concentrations of the hormone are applied. Moreover, it is difficult to determine how much of the exogenously applied hormone is translocated in a biologically active form to a target tissue. A modulation of the cytokinin metabolism by a transgenic approach eliminates some of these problems. Several systems have been designed to overexpress the IPT-gene of Agrobacterium tumefaciens, encoding for isopentenyltransferase, which is a key enzyme of the cytokinin biosynthetic pathway, to obtain elevated endogenous cytokinin content (heat-shock promoter [27]; tetracycline inducible promoter [28]). The use of heat-shock promoters induces additional changes, since a heat-shock has to be applied for the induction of the promoter. Profound analysis of the transgenic plants with a tetracycline inducible promoter showed that no elevation of cytokinin could be found in the leaves [29]. In this study, two transgenic tobacco plant models (Pssu-ipt and 35S: CKX1) were studied. Transgenic (Pssu-ipt) [30] tobacco plants express IPT under control of a light-inducible promoter of the RuBisCo enzyme of Pisum sativum, and 35S:CKX1 transgenic tobacco plants express a gene for cytokinin oxidase/dehydrogenase from A. thaliana under control of a constitutive CaMV 35S promoter and show diminished cytokinin content [31]. A correlation between the expression of the transgene and the altered endogenous cytokinin content has been proven in [32]. To our knowledge, no transcription/proteomic data reports exist on transgenic tobacco plants with diminished endogenous cytokinin content.

Functional analysis, using chlorophyll $a$ fluorescence kinetics, and pigment analysis have already shown that cytokinin affects the photosynthetic apparatus [[31], unpublished observations]. While decreased endogenous cytokinin content diminished the chlorophyll biosynthesis without a significant effect on the photosynthetic activity [31], increased endogenous cytokinin content elevated the chlorophyll content and caused functional differences in the activity of the different parts of the photosynthetic electron transport chain [[33], unpublished observations]. Moreover, the ultrastucture of chloroplasts is dramatically changed in both transgenic tobacco plants $[9,31]$.

To investigate if these functional and structural differences are a consequence of alterations in the chloroplast protein composition, two different proteomic approaches are used: BN/SDS-PAGE and IEF/SDSPAGE in combination with the DIGE technology. IEF/ SDS-PAGE has been proven to resolve large numbers of soluble and peripheral membrane proteins $[34,35]$. However, this technique is not very useful for the separation of highly hydrophobic membrane proteins present in the thylakoid membranes of chloroplasts, such as photosystem I, photosystem II, cytochrome $b_{6} f$, and ATP- 
synthase [36]. These membrane proteins are poorly soluble in the commonly used IEF compatible detergents (such as CHAPS) and tend to precipitate near their isoelectric point. As an alternative, BN/SDS-PAGE is used. This technique is a better method to resolve highly hydrophobic integral membrane proteins from thylakoid membranes [37]. Here it is used to resolve digitonin-solubilized hydrophobic thylakoid proteins and complexes thereof in the first dimension, allowing for a qualitative study of the protein complex polypeptide composition in the second dimension in wild-type and transgenic plants. Finally, DIGE is used to quantitatively analyse the stromal proteome in the same experimental settings. In addition to this proteome analysis, we also investigated the transcription levels of genes encoding proteins that were found to be differently expressed in stroma in response to altered endogenous cytokinin content.

\section{Results}

The studied transgenic 35S:CKX1 and Pssu-ipt tobacco plants show a severely retarded development and differences in growth pattern compared to their corresponding wild-types (respectively Samsun NN and SR1). These morphological and developmental differences as a consequence of the expression of the transgene have already been described by Werner et al. $[31,38,39]$ and by Synková et al. [33].

\subsection{BN/SDS-PAGE of thylakoids}

Isolated thylakoids from plants with altered endogenous cytokinin content were first submitted to BN-PAGE. For this purpose, thylakoid membranes were treated with digitonin, which is known to be a suitable detergent for the solubilisation and stabilisation of supercomplexes $[37,40]$.

Ten different protein complexes were identified using MALDI-TOF/TOF in combination with previously published data [40]. The upper five bands can be assigned to supercomplexes with a high molecular mass. They contain PSI/PSII and associated LHC together with ATP-synthase. Band F corresponds to a supercomplex consisting of PSI/LHCI and PSII (dimeric core). $\mathrm{RuBisCO}$ is the main component of band G. The presence of $\mathrm{RuBisCO}$ in a thylakoid fraction has already been shown by Aro et al. [41] and Timperio et al. [42]. Band $\mathrm{H}$ can be assigned to the PSII/ATP-synthase complex and band I to cytochrome $b_{6} f$. Band J represents the trimeric light-harvesting complex III.

Blue-native separated protein complexes were directly transferred and analysed in a second dimension gel using denaturing SDS-PAGE. Under these conditions, protein complexes dissociate into their subunits, and the protein subunits of the different complexes are separated according to their molecular mass. Figure 1A gives a representative spot map of wild-type Pssu-ipt tobacco thylakoids. An overview of identified spots is given in Table 1 and supplemental data about the identified proteins can be found in Additional file 1, table S1. It should be noted that not all proteins can be identified by this experimental approach. Some proteins are deficient in the basic amino acids arginine and lysine and, therefore, are poorly proteolysed by trypsin. Alternatively, hydrophobic tryptic fragments might be lost during peptide extraction prior to mass spectrometry.

The spot maps obtained from the wild-type tobacco and corresponding transgenic thylakoids were superimposable with no discernable qualitative difference upon image analysis (Figure 1B). Quantitative differences were not taken into consideration.

\subsection{IEF/SDS-PAGE of chloroplast fractions (DIGE)}

The stroma fraction from tobacco chloroplasts was solubilised in a chaotropic CHAPS sample buffer and subjected to 2D-DIGE, as described in section 5.5. Thylakoid membrane proteins are not easily solubilised with used DIGE sample buffer and can cause problems in IEF, as has already been mentioned above. With this constraint in mind, we performed DIGE analysis of both the thylakoid (data not shown) and the stroma fraction.

Figure 2A shows a representative gel image of the stroma fraction containing about 1,500 spots. Comparing Pssu-ipt and 35S:CKX1 with corresponding wild types (Figure 2B-C) showed that 19 spots (Figure 2A, spots labelled 1 to 19) and 9 spots, respectively, (Figure $2 \mathrm{~A}$, spots labelled 20 to 26,6 and 17) were differentially abundant $(\mathrm{p}<0.05$; spot abundance ratio $\geq \pm 1.2)$. Overall mass spectrometric identification rate was unexpectedly low and 10 spots in total could be identified. These included proteins related to the Calvin-Benson cycle (spots 6, 23 and 24), proteins involved in proteolytic processes in chloroplasts (spot 3), in the final step of the electron transport (spot 8), in protection of chloroplasts to oxidative damage (spot 14), and in the oxygen evolving complex (spot 13). An overview of the differently expressed protein spots and identification is given in Table 2. Additional information about the identified proteins can be found in Additional file 2, table S2.

\subsection{Quantitative real-time PCR}

Proteome analysis of the stroma fraction showed that the abundance of several proteins was affected by cytokinin. Transcript level of their encoding genes (NtFNR, $N t S O D B, N t P S B O, N t P S B P$, and $N t P S B Q$ ) were quantified by RT-PCR using the appropriate reference genes (NtRBCS, NtTUB and NtACT9) [32].

$N t S O D B$ is highly expressed in Pssu-ipt tobacco plants, while for NtFNR, NtPSBO, NtPSBP, and NtPSBQ, 


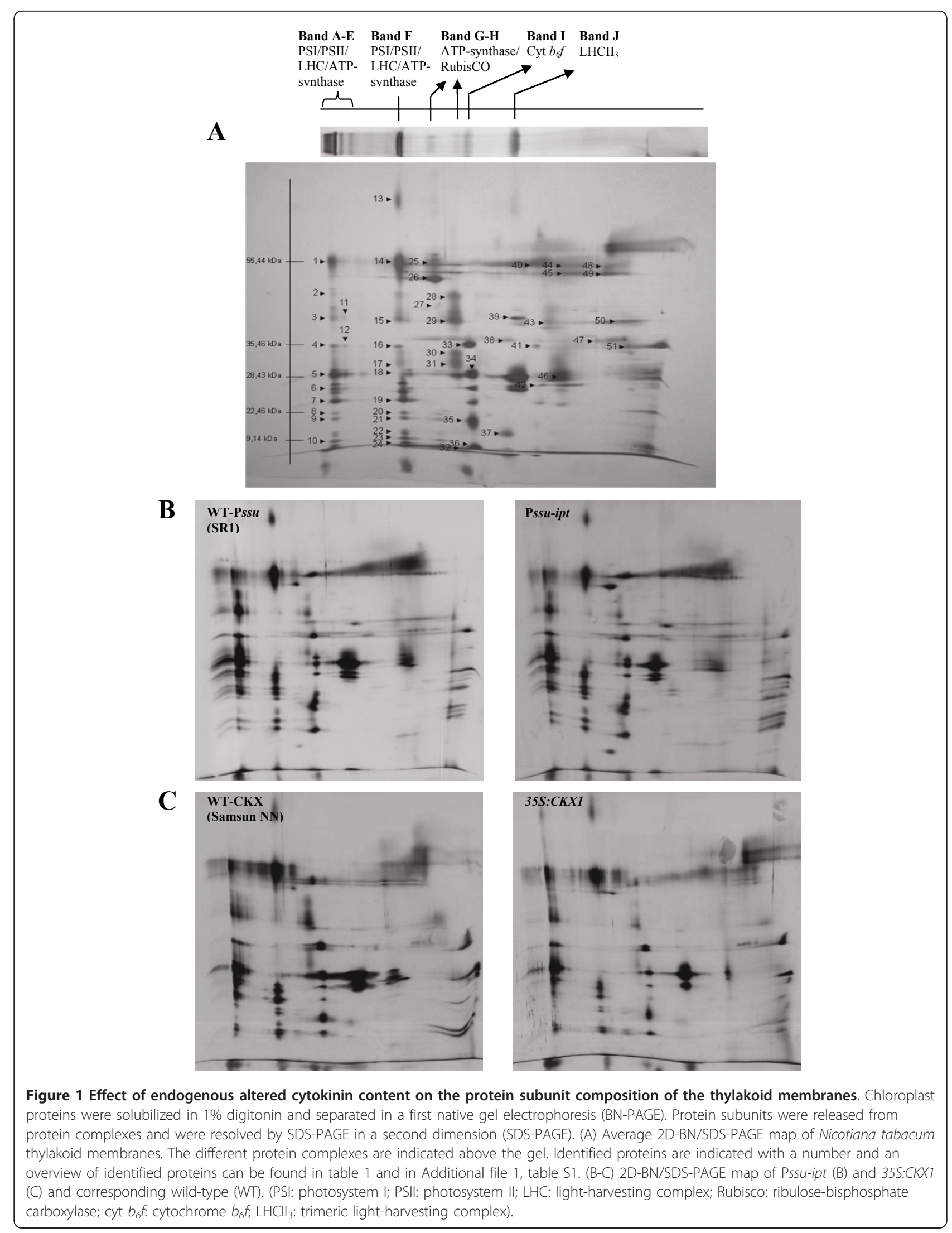


Table 1 Proteins identified by MALDI-TOF/TOF from the second dimension BN/SDS-PAGE

\begin{tabular}{|c|c|c|c|c|}
\hline Spot number & Protein Name & SwissProt Accession number & MW & $\mathrm{pl}$ \\
\hline 1 & ATP synthase subunit alpha, chloroplastic [Nicotiana tabacum] & P00823 & 55477,1 & 5,14 \\
\hline 2 & Photosystem II CP47 chlorophyll apoprotein [Cucumis sativus] & Q2QD63 & 55982,37 & 6,28 \\
\hline 3 & Photosystem II CP43 chlorophyll apoprotein [Ranunculus macranthus] & Q4FFN5 & 52017,79 & 6,68 \\
\hline 4 & Oxygen-evolving enhancer protein 1, [chloroplastic Nicotiana tabacum] & Q40459 & 35377,09 & 5,89 \\
\hline 5 & Chlorophyll a-b binding protein 40 , chloroplastic [Nicotiana tabacum] & P27495 & 28450,22 & 5,48 \\
\hline 6 & Chlorophyll a-b binding protein 13 , chloroplastic [Solanum lycopersicum] & P27489 & 28661,44 & 5,09 \\
\hline 7 & Chlorophyll a-b binding protein 6A, chloroplastic [Solanum lycopersicum] & P12360 & 26785,52 & 5,82 \\
\hline 8 & Photosystem I reaction center subunit II, chloroplastic [Nicotiana sylvestris] & P29302 & 22466,7 & 9,78 \\
\hline 9 & Photosystem I reaction center subunit II, chloroplastic [Nicotiana sylvestris] & P29302 & 22466,7 & 9,78 \\
\hline 10 & Photosystem I reaction center subunit III, chloroplastic [Spinacia oleracea] & P12355 & 25567,52 & 9,4 \\
\hline 11 & Photosystem II CP43 chlorophyll apoprotein [Aethionema grandiflora] & A4QJJ5 & 52042,77 & 6,71 \\
\hline 12 & Oxygen-evolving enhancer protein 1, chloroplastic [Nicotiana tabacum] & Q40459 & 35377,09 & 5,89 \\
\hline 13 & Ribulose bisphosphate carboxylase large chain (Fragment) [Nelumbo lutea] & Q05800 & 44231,36 & 6,4 \\
\hline 14 & Photosystem I P700 chlorophyll a apoprotein A1 [Nicotiana tomentosiformis] & Q33C36 & 83206,56 & 6,67 \\
\hline 15 & Photosystem II CP43 chlorophyll apoprotein [Ranunculus macranthus] & Q4FFN5 & 52017,79 & 6,68 \\
\hline 16 & Oxygen-evolving enhancer protein 1, chloroplastic [Nicotiana tabacum] & Q40459 & 35377,09 & 5,89 \\
\hline 17 & Photosystem II D2 protein [Dioscorea elephantipes] & A6MMK2 & 39765,89 & 5,34 \\
\hline 18 & Chlorophyll a-b binding protein 40, chloroplastic [Nicotiana tabacum] & P27495 & 28450,22 & 5,48 \\
\hline 19 & Chlorophyll a-b binding protein 6A, chloroplastic [Solanum lycopersicum] & P12360 & 26785,52 & 5,82 \\
\hline 20 & Photosystem I reaction center subunit II, chloroplastic [Nicotiana sylvestris] & P29302 & 22466,7 & 9,78 \\
\hline 21 & Photosystem I reaction center subunit II, chloroplastic [Nicotiana sylvestris] & P29302 & 22466,7 & 9,78 \\
\hline 22 & Photosystem I reaction center subunit IV B, chloroplastic [Nicotiana sylvestris] & Q41229 & 15214,74 & 9,74 \\
\hline 23 & Photosystem I reaction center subunit III, chloroplastic [Flaveria trinervia] & P46486 & 25366,48 & 9,35 \\
\hline 24 & Cytochrome b559 subunit alpha [Arabidopsis thaliana] & P56779 & 9380,7 & 4,83 \\
\hline 25 & ATP synthase subunit alpha, chloroplastic [Nicotiana tabacum] & P00823 & 55477,1 & 5,14 \\
\hline 26 & Ribulose bisphosphate carboxylase large chain [Nicotiana sylvestris] & Q3C1J4 & 53377,98 & 6,41 \\
\hline 27 & Ribulose bisphosphate carboxylase large chain (Fragment) [Adoxa moschatellina] & P28378 & 52159,14 & 6,13 \\
\hline 28 & Photosystem II CP47 chlorophyll apoprotein [Barbarea verna] & A4QKD1 & 56204,47 & 6,4 \\
\hline 30 & Photosystem Q(B) protein [Leptosira terrestri] & A6YGB8 & 38353,08 & 5,52 \\
\hline 31 & Photosystem Q(B) protein [Leptosira terrestris] & A6YGB8 & 38353,08 & 5,52 \\
\hline 32 & Cytochrome b559 subunit alpha [Arabidopsis thaliana] & P56779 & 9380,7 & 4,83 \\
\hline 33 & Apocytochrome f [Nicotiana tabacum] & P06449 & 35337,77 & 9,12 \\
\hline 35 & Cytochrome b6-f complex iron-sulfur subunit 2, chloroplastic [Nicotiana tabacum] & Q02585 & 24491,28 & 8,15 \\
\hline 36 & Cytochrome b6-f complex subunit 4 [Agrostis stolonifera] & A1EA39 & 17534,51 & 6,56 \\
\hline 37 & ATP synthase subunit b, chloroplastic [Nicotiana tabacum] & yP06290 & 20917,96 & 8,76 \\
\hline 38 & Ferredoxin-NADP reductase, leaf-type isozyme, chloroplastic [Nicotiana tabacum] & O04977 & 40704,59 & 8,37 \\
\hline 39 & Fructose-bisphosphate aldolase, chloroplastic [Spinacia oleracea] & P16096 & 42726,8 & 6,85 \\
\hline 40 & Photosystem II 22 kDa protein, chloroplastic [Nicotiana tabacum] & Q9SMB4 & 29068,73 & 6,04 \\
\hline 41 & Apocytochrome f [Nicotiana tabacum] & P06449 & 35337,77 & 9,12 \\
\hline 42 & Photosystem II 22 kDa protein, chloroplastic [Nicotiana tabacum] & Q9SMB4 & 29068,73 & 6,04 \\
\hline 43 & Photosystem II CP43 chlorophyll apoprotein [Aethionema grandiflora] & A4QJJ5 & 52042,77 & 6,71 \\
\hline 44 & ATP synthase subunit beta, chloroplastic [Nicotiana plumbaginifolia] & P69370 & 53548,81 & 5,09 \\
\hline 45 & ATP synthase subunit alpha, chloroplastic [Nicotiana tabacum] & P00823 & 55477,1 & 5,14 \\
\hline 46 & Chlorophyll a-b binding protein CP26, chloroplastic [Arabidopsis thaliana] & Q9XF89 & 30194,7 & 6 \\
\hline 47 & Ferredoxin-NADP reductase, leaf-type isozyme, chloroplastic [Nicotiana tabacum] & O04977 & 40704,59 & 8,37 \\
\hline 48 & ATP synthase subunit alpha, chloroplastic [Nicotiana tabacum] & P00823 & 55477,1 & 5,14 \\
\hline
\end{tabular}


Table 1 Proteins identified by MALDI-TOF/TOF from the second dimension BN/SDS-PAGE (Continued)

\begin{tabular}{rlrrr}
\hline 49 & ATP synthase subunit alpha, chloroplastic [Nicotiana tabacum] & P00823 & 55477,1 & 5,14 \\
\hline 50 & ATP synthase gamma chain, chloroplastic [Nicotiana tabacum] & P29790 & 41705,96 & 8,16 \\
\hline 51 & ATP synthase subunit beta, chloroplastic [Nicotiana tabacum] & P00826 & 53577,78 & 5 \\
\hline 52 & Oxygen-evolving enhancer protein 1, chloroplastic [Nicotiana tabacum] & Q40459 & 35377,09 & 5,89 \\
\hline
\end{tabular}

Additional information about the identified proteins can be found in Additional file 1, table S1.

the opposite observation is made (Figure 3A). Within the 35S:CKX1 tobacco plants the expression levels of only NtFNR and NtPSBO are elevated, (Figure 3B) in comparison with wild-type plants. For fructose-1,6bisphosphate aldolase, which is found to be affected by cytokinin in this study, quantification of the associated transcript is not possible since sequence details are not yet publicly available for this Nicotiana tabacum enzyme.

\section{Discussion}

\subsection{BN/SDS-PAGE and IEF/SDS-PAGE complement each} other to study the effects of cytokinins on the proteome of chloroplasts

Although BN/SDS-PAGE was restricted to the thylakoid membrane fraction, we found the presence of some stroma proteins ( $\mathrm{RuBisCO}$, plastidic aldolase and ferredoxin-NADP reductase). This could be due to contamination, although it is possible that these proteins associate with the thylakoid membrane to function more efficiently. This kind of association has already been demonstrated in Anacystis nidulans, where several enzymes involved in the Calvin-Benson cycle are closely associated with the thylakoid membranes to get better access to ATP and NADPH, produced during the electron transfer [43]. The presence of RuBisCO in BN-gels has also been shown by Aro et al. [41] and Timperio et al. [42].

Our results indicate that there is no qualitative difference in the oligomeric assembly state of protein complexes and subunit composition between transgenic and wild-type plants, as judged from proteome maps generated by BN/SDS-PAGE. However, changes observed in photosynthetic activity in response to altered endogenous cytokinin content $[33,39]$ may still be related to a quantitative difference in subunit composition of the membrane protein complexes.

The easily soluble stroma fraction was subjected to IEF/SDS-PAGE to obtain information on the quantitative changes induced by elevated/reduced endogenous cytokinin content in the chloroplast. IEF/SDS-PAGE of the fluorescent labelled stroma fraction showed that there were only a few quantitative differences in protein composition between the wild-type and transgenic plants. These differences are related to proteolytic processes, electron transport, protection against oxidative damage, and the oxygen evolving complex.

Both chloroplastic superoxide dismutase (Fe) (spot 14) and ferredoxin-NADP+ reductase (spot 8) have a higher protein abundance in Pssu-ipt transgenic tobacco. Both proteins can be correlated to protection against photooxidative damage. Superoxide is formed at any location in which an electron transport chain and $\mathrm{O}_{2}$ are present, such as in photosystem I in chloroplasts (Mehler-reaction). It is believed that the major task of chloroplastic SOD in plants is to remove superoxide that is produced by electron leakage to oxygen at the reducing site of photosystem I. FeSOD is localised in the chloroplasts and involved in the protection of both the plasmamembrane and PSII against oxidative damage [44]. This observation corresponds to the study of [45], who demonstrated that cytokinin induces the activity of antioxidant enzymes during ontogeny. The increased amount of FNR, which catalyses the electron transfer from ferredoxin to $\mathrm{NADP}^{+}$, can also be correlated to photo-oxidative protection. A recent study demonstrated that tobacco plants overexpressing ferredoxin-NADP +reductase showed augmented tolerance to photo-oxidative damage and redox-cycling oxidants [46]. Cerny et al. [26] also found an increased level of FNR in the early cytokinin-response proteins.

The chloroplast homologue of ClpA (Caseinolytic protease - designated $\mathrm{ClpC}$ ), which has a higher protein level in Pssu-ipt tobacco plants, is encoded in the nucleus [47] and imported posttranslationally into the stroma. It is an ATP-dependent unfoldase involved in the degradation of mistargeted proteins in the stroma and the degradation of chloroplast protein complexes with an unbalanced stoichiometry and damaged proteins by feeding the unfolded proteins to the ClpP proteolytic complex. It is known that Clp proteases also play an important role in the development of chloroplasts in Arabidopsis thaliana [48-50]. This suggests that there could be a correlation between the higher protein level of ClpA and chloroplast development in Pssu-ipt tobacco plants. These plants have chloroplasts with a specific ultrastructure: they contain more grana stackings and increased starch grains, as described by Synková et al. [9]. Moreover, Lochmanova et al. [25]. found an induction of a Clp protease. 


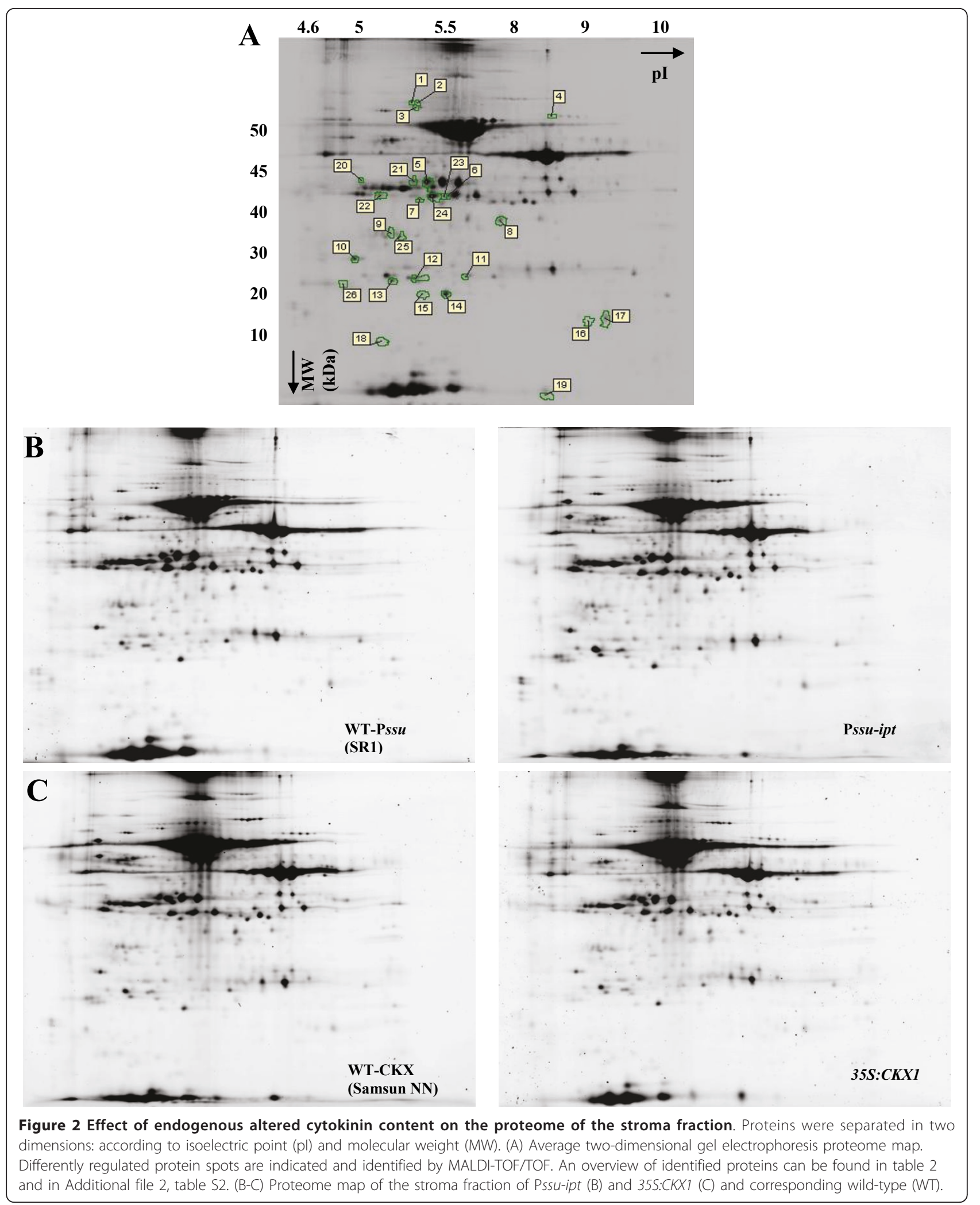


Table 2 Summary of proteins different in spot abundance ratio between wild-type and transgenic tobacco plants in stroma fraction

\begin{tabular}{|c|c|c|c|c|c|}
\hline \multicolumn{6}{|c|}{ Stroma fraction Pssu-ipt versus wild-type (SR1) } \\
\hline $\begin{array}{c}\text { Spot } \\
\text { number }\end{array}$ & Protein name + SwissProt accession number & MW & $\mathrm{pl}$ & $\begin{array}{l}\text { Fold } \\
\text { change }\end{array}$ & p-value \\
\hline 1 & Not identified & - & - & 1.76 & 0.012 \\
\hline 2 & Not identified & - & - & 1.71 & 0.047 \\
\hline 3 & $\begin{array}{l}\text { ATP-dependent Clp protease ATP-binding subunit clpA homolog CD4B, chloroplastic } \\
\text { [Solanum lycopersicum] P31542 }\end{array}$ & 102462.8 & 5.86 & 1.98 & 0.039 \\
\hline 4 & Not identified & - & - & -1.44 & 0.023 \\
\hline 5 & Not identified & - & - & 4.47 & 0.025 \\
\hline 6 & Probable fructose-bisphosphate aldolase 1, chloroplastic [Arabidopsis thaliana] Q9SJU4 & 43074.98 & 6.18 & 2 & 0.0114 \\
\hline 7 & Not identified & - & - & 1.91 & 0.0114 \\
\hline 8 & Ferredoxin-NADP reductase, leaf-type isozyme, chloroplastic [Nicotiana tabacum] O04977 & 40704.59 & 8.37 & 1.8 & 0.0134 \\
\hline 9 & Not identified & - & - & 2.18 & 0.046 \\
\hline 10 & Not identified & - & - & 1.99 & 0.0114 \\
\hline 11 & Not identified & - & - & 1.9 & 0.039 \\
\hline 12 & Not identified & - & - & 2.23 & 0.043 \\
\hline 13 & Oxygen-evolving enhancer protein 2-1, chloroplastic [Nicotiana tabacum] Q7DM39 & 28805.44 & 6.84 & 3.02 & 9.40E-03 \\
\hline 14 & Superoxide dismutase [Fe], chloroplastic (Fragment) [Nicotiana plumbaginifolia] P22302 & 23027.52 & 5.53 & 4.84 & $6.70 \mathrm{E}-03$ \\
\hline 15 & Not identified & - & - & 2.97 & $6.7 \mathrm{E}-03$ \\
\hline 16 & Not identified & - & - & 2.37 & 0.0146 \\
\hline 17 & Not identified & - & - & 1.96 & 0.0146 \\
\hline 18 & Not identified & - & - & 1.48 & 0.0146 \\
\hline 19 & Not identified & - & - & -1.57 & $6.7 \mathrm{E}-03$ \\
\hline
\end{tabular}

Stroma fraction 35S:CKX1 versus wild-type (Samsun NN)

\begin{tabular}{|c|c|c|c|c|c|}
\hline $\begin{array}{c}\text { Spot } \\
\text { number }\end{array}$ & Protein name + SwissProt accession number & MW & $\mathrm{pl}$ & $\begin{array}{l}\text { Fold } \\
\text { change }\end{array}$ & p-value \\
\hline 6 & Probable fructose-bisphosphate aldolase 1, chloroplastic [Arabidopsis thaliana] Q9SJU4 & 43074.98 & 6.18 & 1.42 & 5.46E-03 \\
\hline 17 & Not identified & - & - & -1.46 & $5.46 \mathrm{E}-03$ \\
\hline 20 & Not identified & - & - & -1.45 & 5.46E-03 \\
\hline 21 & Not identified & - & - & 1.45 & 0.0103 \\
\hline 22 & Not identified & - & - & 1.24 & 9.43E-03 \\
\hline 23 & Probable fructose-bisphosphate aldolase 1, chloroplastic [Arabidopsis thaliana] Q9SJU4 & 43074.98 & 6.18 & 1.36 & $5.46 \mathrm{E}-03$ \\
\hline 24 & Probable fructose-bisphosphate aldolase 1, chloroplastic [Arabidopsis thaliana] Q9SJU4 & 43074.98 & 6.18 & 1.39 & 5.46E-03 \\
\hline 25 & Not identified & - & - & 1.3 & 9.43E-03 \\
\hline 26 & Not identified & - & - & -1.66 & 9.43E-03 \\
\hline
\end{tabular}

Proteins were identified by MALDI-TOF/TOF. The fold change indicates the difference in expression relative to wild-type plants. Additional information about the identified proteins can be found in Additional file 2, table S2.

Fructose bisphosphate aldolase (spots 6, 23 and 24), which catalyses the conversion of glyceraldehyde 3phosphate with dihydroxyacetone to fructose 1,6-bisphosphate, has an increased protein level in both Pssu-ipt and in 35S:CKX1 tobacco plants. The higher protein level in 35S:CKX1 is in correspondence with the higher enzyme activity, as demonstrated by Werner et al. [31]. They correlated the higher activity of aldolase with a compensation mechanism to a lowered sugar status as a consequence of the altered sink-to-source relation. The increased level in Pssu-ipt tobacco plants is in correspondence with Cerny et al. [26], who also found an upregulation of fructose bisphosphate aldolase in Arabidopsis thaliana after induction with cytokinin.

Remarkably, there was only a small amount of differentially expressed proteins in our study. Although this is not completely unexpected, since we used only the purified stroma fraction for analysis, while other studies often use total protein extracts $[25,26]$. Moreover, these studies used a different system to investigate the effect 


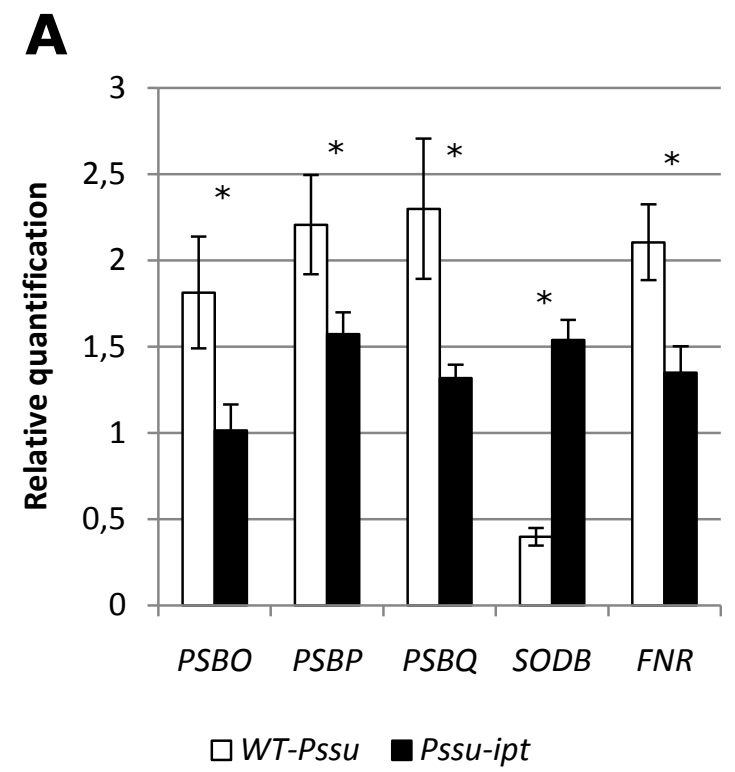

B

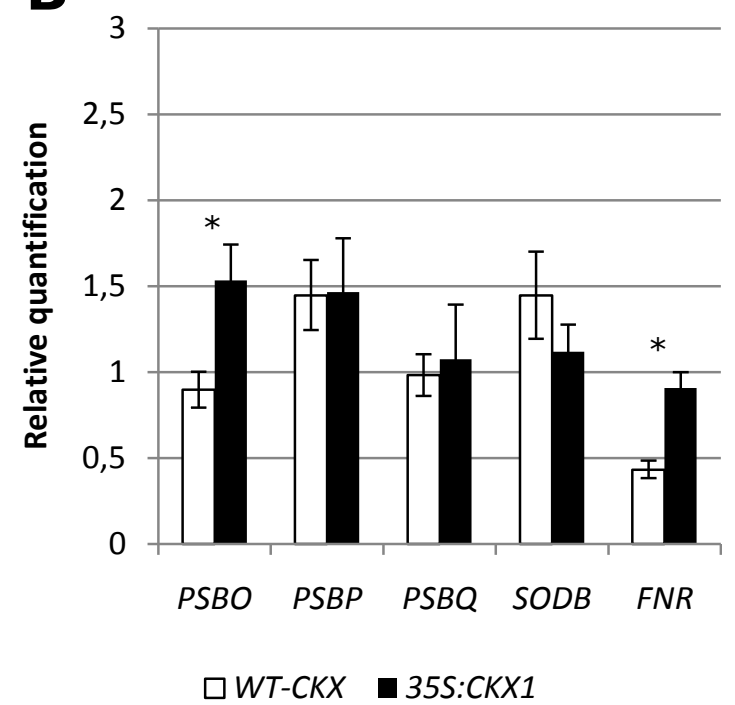

Figure 3 Effect of endogenous altered cytokinin content on transcript. Transcription levels of genes encoding differently expressed proteins in transgenic tobacco plants (NtFNR, NtPSBP, $N t S O D B$ ) and genes encoding subunits of the OEC (NtPSBO and NtPSBQ) for (A) transgenic Pssu-ipt tobacco plants and (B) 35S:CKX1 tobacco plants and corresponding wild-types. All values are presented with SE. Statistical significant differences $(p<0.05)$ are indicated $\left(^{*}\right)$.

of cytokinin: exogenous application of cytokinin to 7day-old Arabidopsis seedlings [26] or a dexamethasoneinducible system [25], which makes a direct comparison to our study difficult.

Comparison of the proteome results obtained by the analysis of transgenic tobacco plants with elevated/ diminished endogenous cytokinin content compared to their corresponding wild-types revealed that only one common protein, fructose-bisphosphate aldolase 1, was similarly influenced by the altered cytokinin status. This can be explained by the different genetic background of both transgenic plants and by the different mode of action of cytokinin.

\subsection{Transcription level of photosynthetic genes and comparison with proteome data}

We evaluated the transcript levels of genes encoding proteins that were differently expressed in the studied transgenic tobacco plants. A straightforward correlation between the transcript and protein level is however not possible. This has already been indicated by Gygi et al. [51]. Moreover, in our analysis, material of different leaves was used for proteome and transcript analyses. Nevertheless, quantitative real-time PCR showed that the transcript levels of the investigated genes are differently expressed in the transgenic plants.

The decreased transcript levels of the investigated genes in Pssu-ipt tobacco plants and opposite effects on mRNA levels (for PSBO and FNR) in cytokinin deficient plants can be explained by the effect of cytokinins on the complex signalling process that controls the expression of most nuclear-encoded and some plastid-encoded photosynthesis genes. The redox state of the electron transport chain, tetrapyrrole intermediates and reactive oxygen species provide a positive and negative feedback loop to regulate the expression of the photosynthesis genes and these processes can be influenced by cytokinins $[16,33,52]$.

The higher expression in Pssu-ipt transgenic tobacco plants is possibly a consequence of the effects of cytokinin on electron transfer (reduced activity at PSI results in the production of superoxide) to induce oxidative stress. A complex control network is activated to reduce the effects of oxidative stress and the transcriptional regulation of $N t S O D B$ is possibly part of this network.

These results clearly indicate that the transcriptional regulation of photosynthesis genes and the involvement of cytokinin in this regulation network is rather complex and needs further elucidation.

\section{Conclusion}

In this study, we have evaluated the role of cytokinin in the structure and function of the photosynthetic apparatus. Although cytokinin is known to have distinct effects on chloroplast ultrastructure and function, only a few differences were found on protein level. The altered endogenous cytokinin content does not structurally change the subunit composition of the supercomplexes, and IEF/SDS-PAGE showed that cytokinins induce some significant changes in the proteome of the stroma fraction, which could be correlated to protection against oxidative stress. 


\section{Materials and methods}

\subsection{Plant material and growth conditions}

All plants were grown in a greenhouse during spring time (temperature $24^{\circ} \mathrm{C} / 18^{\circ} \mathrm{C}$, average humidity $60 \%$ ). Additional illumination was provided $16 \mathrm{~h}$ a day with AgroSon T (400W) and HTQ (400W) lamps (photon flux density of $200 \mu \mathrm{mol}$ quanta $\left.\left(\mathrm{m}^{-2} \mathrm{~s}^{-1}\right)\right)$. Two different types of transgenic tobacco plants with altered cytokinin metabolism and the corresponding wild types were used.

1. Transgenic tobacco plants (Nicotiana tabacum L. cv. Petit Havana SR1) containing the IPT-gene under control of the Pisum sativum ribulose-1,5-biphosphate carboxylase small subunit promoter sequence (Pssu-ipt) were obtained using the Agrobacterium tumefaciens system, as described by Beinsberger et al. [30]. After transformation, the seeds were sown on Murashige and Skoog medium with kanamycin $(100 \mathrm{mg} / \mathrm{ml})$. Corresponding wild-type plants (SR1) were cultivated under the same conditions without kanamycin. Only kanamycin resistant transgenic seedlings (2-3 weeks old) were transferred to potting soil (Universal potting soil, Agrofino, Agrofino Products N.V.) and further cultivated under the same conditions as wild-type plants. Soil was supplemented with half-strength Hoagland solution.

2. Tobacco plants (Nicotiana tabacum L. var. Samsun NN) (35S:AtCKX1), overexpressing a gene for cytokinin oxidase/dehydrogenase from Arabidopsis thaliana under control of a constitutive CaMV 35S promoter [38], were first cultivated in vitro on Murashige and Skoog medium with hygromycin $(15 \mathrm{mg} /$ 1). Corresponding wild-type plants (Samsun) were cultivated under the same conditions without hygromycin. The hygromycin resistant seedlings and wildtype plants were transferred to potting soil under the same conditions as described for the Pssu-ipt plants.

To homogenize the experiments, plants of the same height were used: 7-week-old wild-type plants (SR1: 32.7 $\pm 4.1 \mathrm{~cm} ; \mathrm{n}=15$ and Samsun: $7.5 \pm 1.4 \mathrm{~cm} ; \mathrm{n}=15)$, 18-week-old Pssu-ipt plants $(35 \pm 2 \mathrm{~cm} ; \mathrm{n}=15)$ and 14week-old $C K X$ tobacco plants $(7.5 \pm 1.1 \mathrm{~cm} ; \mathrm{n}=15)$.

\subsection{Isolation of intact chloroplasts and chloroplast fractions}

In each out of four independent experiments, intact chloroplasts were isolated from the upper four leaves larger than $5 \mathrm{~cm}$ of six plants of each of the two transgenic and the two wild-type lines, following a modified method described in Bartlett [53]. Leaves (50 g) were harvested at the same time in the morning and homogenized in $200 \mathrm{ml}$ of ice-cold grinding buffer $(2.0$ mM NaEDTA; $1.0 \mathrm{mM} \mathrm{MgCl} 2 ; 1.0 \mathrm{mM} \mathrm{MnCl}_{2} ; 50.0$ $\mathrm{mM}$ Hepes/KOH, pH 7.5; $0.33 \mathrm{M}$ sorbitol; $5.0 \mathrm{mM}$ sodiumascorbate) using a Braun MX-32 mixer. The suspension was filtered through four layers of miracloth (pore size: $22-25 \mu \mathrm{m}$ ) and chloroplasts were sedimented by centrifugation (1400 g, $5 \mathrm{~min}$ ). The pellet was resuspended in grinding buffer $(5 \mathrm{ml} / 50 \mathrm{~g})$ and $2 \mathrm{ml}$ of this suspension was loaded on a continuous 10-80\% Percoll gradient (3\% PEG 6000; 1\% Ficoll; 1\% BSA) and centrifuged for $20 \mathrm{~min}$ at $8000 \mathrm{~g}$. Two green bands were visible after centrifugation. The lower band containing the intact chloroplasts was collected, washed with 5-10 volumes of grinding buffer and centrifuged for $10 \mathrm{~min}$. The intact chloroplasts were used for the isolation of thylakoid for $\mathrm{BN}$ and for chloroplast subfraction isolation. For BN, the intact chloroplasts were resuspended in TMK-buffer (10 mM Tris pH 6.8; $10 \mathrm{mM} \mathrm{MnCl}_{2} ; 20$ $\mathrm{mM} \mathrm{KCl}$ ) and centrifuged for $10 \mathrm{~min}$ at $2200 \mathrm{~g}$. The pellet was solved in TMK buffer ( $1 \mathrm{mg}$ chlorophyll $/ \mathrm{ml}$ ) and stored at $-70^{\circ} \mathrm{C}$

To obtain the chloroplast subfractions, the intact chloroplasts were resuspended in $3 \mathrm{ml}$ resuspension buffer (25 mM HEPES pH 7.5, 10 mM EDTA). The resuspended chloroplasts were homogenized using a glass homogenizer with a Teflon pestle, put on top of a discontinuous sucrose gradient $(1.9 \mathrm{M}, 1.30 \mathrm{M}$ and $1.14 \mathrm{M}$ sucrose in $25 \mathrm{mM}$ HEPES $\mathrm{pH} 7.5)$ and centrifuged for $90 \mathrm{~min}$ at $100,000 \mathrm{~g}$. After centrifugation, different chloroplast fractions can be distinguished: the stroma fraction (top of the gradient), the envelope fraction and the thylakoid fraction (dark green bands). The stroma fraction was frozen at $-70^{\circ} \mathrm{C}$ until protein extraction.

\subsection{Protein extraction of chloroplast subfraction}

Proteins from the thylakoid fraction were extracted with $9 \mathrm{ml}$ chloroform/methanol (7:2). The resulting mixture was put on ice for $20 \mathrm{~min}$ before centrifugation $(20 \mathrm{~min}$ at $12,000 \mathrm{~g}$ ). The pellet was dried under N2 and solubilized in DIGE sample buffer (7 M urea, $2 \mathrm{M}$ thiourea, 4\% CHAPS, $30 \mathrm{mM}$ Tris, $\mathrm{pH} 8.8$ ).

Proteins from the stroma were concentrated using TCA (trichloro-acetic acid) precipitation. An equal amount of ice-cold $20 \%$ TCA (w/v) was added to the stroma fraction and incubated for $1 \mathrm{~h}$ at $4^{\circ} \mathrm{C}$. After incubation, the suspension was centrifuged for $10 \mathrm{~min}$ at $3000 \mathrm{~g}$. The pellet was washed with methanol-diethylether (1:1) and centrifuged under the same conditions. Afterwards, the pellet was washed with $100 \%$ diethylether and centrifuged again under the same conditions. The pellet of the last centrifugation was dried under $\mathrm{N}_{2}$ and solubilized in DIGE sample buffer (7 M urea, $2 \mathrm{M}$ thio-urea, $4 \% \mathrm{CHAPS})$. The protein concentration of 
these samples was determined by using the 2D-QuantKit (GE Healthcare/Amersham Biosciences, Freiburg, Germany).

\subsection{BN/SDS-PAGE BN-PAGE/SDS-PAGE}

BN-PAGE was performed according to Reisinger et al. [54]. Before solubilization, the enriched thylakoid suspension (in TMK buffer) was centrifuged at $400 \mathrm{~g}$ for 3 min. The pelleted thylakoids $(50 \mu \mathrm{l})$ were then solubilized with $2.5 \%(\mathrm{w} / \mathrm{v})$ digitonin for $10 \mathrm{~min}$ at $4{ }^{\circ} \mathrm{C}$. After solubilization, the samples were centrifuged for $10 \mathrm{~min}$ at $13,000 \mathrm{~g}$. One $\mu \mathrm{l}$ loading buffer $(5 \%(\mathrm{w} / \mathrm{v})$ Serva Blue G250, $750 \mathrm{mM} \varepsilon$-aminocaproic acid) was added to the supernatans and the mixture was loaded on a $5-15 \%$ acrylamide gradient gel (4\% acrylamide stacking gel). Electrophoresis was performed in a Protean II electrophoresis system (Bio-Rad, USA) at $4^{\circ} \mathrm{C}$, applying a constant voltage of $250 \mathrm{~V}$ overnight. For SDS-PAGE, lanes of the BN-PAGE were first incubated in solubilization buffer (2\% (w/v) SDS, $66 \mathrm{mM} \mathrm{Na} \mathrm{CO}_{3}, 2 \%(\mathrm{w} / \mathrm{v}) \beta$-mercapto-ethanol, 10\% (w/v) glycerol, $0.5 \mathrm{M}$ Tris/HCl, $\mathrm{pH}$ 6.8) for $30 \mathrm{~min}$ at room temperature, subsequently put on a second dimension gel (10\% acrylamide; stacking gel: $4 \%$ acrylamide) and overlaid with agarose solution (25 mM Tris/ $\mathrm{HCl}, \mathrm{pH} 8.8,192 \mathrm{mM}$ glycine, 0.1\% SDS, $0.5 \%(\mathrm{w} / \mathrm{v})$ agarose, $0.0002 \%$ bromophenolblue). Electrophoresis $(1 \mathrm{~h}$ at $2 \mathrm{~W} /$ gel, followed by $1 \mathrm{~h}$ at $4 \mathrm{~W} /$ gel and, finally, $4 \mathrm{~h}$ at $17 \mathrm{~W} / \mathrm{gel}$ ) was carried out in the EttanDALTsix system (GE Healthcare).

\section{Staining and data analysis}

The gels were fixed in fixation solution $(45 \%(\mathrm{v} / \mathrm{v})$ methanol, 5\% (v/v) acetic acid) overnight. The BN-gels (first dimension) were stained with Coomassie dye (50\% (v/v) methanol, 7\% (v/v) acetic acid, 0.025\% (w/v) Coomassie Brilliant Blue G250) for $4 \mathrm{~h}$ and destained overnight in destaining solution (50\% (v/v) methanol, 7\% (v/ $\mathrm{v})$ acetic acid); after fixation, the second dimension gels were washed three times with $50 \%(\mathrm{v} / \mathrm{v})$ ethanol for 20 min, incubated for $1 \mathrm{~min}$ in $0.02 \%(\mathrm{w} / \mathrm{v}) \mathrm{Na}_{2} \mathrm{SO}_{4}$ and rinsed three times with water. Thereafter, the gels were incubated for $20 \mathrm{~min}$ in $0.2 \%(\mathrm{w} / \mathrm{v})$ silver nitrate, rinsed three times with MilliQ water and incubated in $0.04 \%$ formaldehyde and $6 \%(\mathrm{w} / \mathrm{v})$ sodium carbonate until the spots were visible. The staining reaction was stopped using 5\% (v/v) acetic acid. After staining, the gels (in duplicate) of four biologically independent chloroplast extractions were scanned and analysed with Image Master Platina (Amersham Bioscience).

\section{Proteolysis and peptide extraction}

The protein spots from the second dimension (BN/SDSPAGE) were detected using Image Master 5.0 (GE Healthcare), selected for picking by a gel cutting station (ProxCision, PerkinElmer, USA) and collected in a microtiter plate (ThermoFast semi skirted, Abgene, UK). The gel plugs were subjected to two wash steps: water $\left(5 \%(\mathrm{v} / \mathrm{v}) \mathrm{CH}_{3} \mathrm{CN}\right)$ and acetonitrile $\left(5 \%(\mathrm{v} / \mathrm{v}) \mathrm{H}_{2} \mathrm{O}\right)$ on a liquid handling robot (MultiProbeII HT, PerkinElmer). The dehydrated gel particles were rehydrated in $5 \mu \mathrm{l}$ of digest buffer containing $83 \mathrm{ng}$ trypsin (MS Gold; Promega, USA), $50 \mathrm{mM} \mathrm{NH}_{4} \mathrm{HCO}_{3}$ and $5 \%$ (v/v) $\mathrm{CH}_{3} \mathrm{CN}$ for $16 \mathrm{~min}$ at $4^{\circ} \mathrm{C}$. After the addition of $15 \mu \mathrm{l}$ of a buffer containing $50 \mathrm{mM} \mathrm{NH}_{4} \mathrm{HCO}_{3}$ and $5 \%(\mathrm{v} / \mathrm{v}) \mathrm{CH}_{3} \mathrm{CN}$, proteins were digested at $38^{\circ} \mathrm{C}$ for $3 \mathrm{~h}$. The resulting peptides were desalted and concentrated with microcolumn solid phase tips (PerfectPuretM C18 tip, $200 \mathrm{nl}$ bed volume; Eppendorf, Germany) and eluted directly onto a MALDI target plate (OptiMALDI; Applied Biosystems, USA) with $1.0 \mu \mathrm{l}$ of $50 \% \mathrm{CH}_{3} \mathrm{CN}, 0.1 \%$ $\mathrm{CF}_{3} \mathrm{COOH}$ solution saturated with cyano-4-hydroxycinnamic acid and spiked with $25 \mathrm{fmol} / \mu \mathrm{l}$ Glu1-fibrinopeptide B (Sigma-Aldrich Chemie GmbH, Germany), 25 $\mathrm{fmol} / \mu \mathrm{l}$ des-Pro2-Bradykinin (Sigma-Aldrich) and 50 $\mathrm{fmol} / \mu \mathrm{l}$ Adrenocorticotropic Hormone Fragment 18-39 human (Sigma-Aldrich).

\section{Acquisition of Mass Spectra}

A MALDI-TOF/TOF MS instrument (4800 Proteomics Analyser Plus; Applied Biosystems, Foster City, USA) was used to acquire peptide mass fingerprints (PMFs) and peptide sequence spectra. Each MALDI plate was calibrated according to the manufacturer's specifications. All PMF spectra were internally calibrated with the spiked internal standards, resulting in an average mass accuracy of $5 \pm 10 \mathrm{ppm}$. Using the individual PMF spectra, up to eight peptides exceeding a signal-to-noise ratio of 100 that passed through a mass exclusion filter were submitted to CID fragmentation. The subsequent fragmentation spectra were calibrated using default calibration.

\section{MS-based Protein Homology Identification}

PMF and peptide sequence spectra of each sample were processed with the accompanied software suit (GPS Explorer 3.5 - Applied Biosystems) and submitted for protein homology identification by using a local database search engine (Mascot 2.1; Matrix Science, London, UK) (SwissProt, Viridiplantae (Green Plants), 27901 sequences, 27 July 2009 at 11:27:15 GMT)). The maximum number of missed cleavages was set to two. The variable modifications selected for searching includd oxidation of methionine and carbamidomethylation of cystein. A peptide mass tolerance of $\pm 40 \mathrm{ppm}$, a fragment mass tolerance of $\pm 0.4 \mathrm{Da}$ and a peptide charge of +1 were selected. Only significant hits, as defined by the MASCOT probability analysis $(\mathrm{p}<0.05)$, were accepted.

\subsection{IEF/SDS-PAGE}

\section{Protein labelling and experimental design}

The proteins were labelled (stroma: $50 \mu \mathrm{g}$ proteins) with 200 pmol of the CyDyes, according to the 
manufacturer's protocol (Amersham Biosciences/GE Healthcare). The proteins from wild-type and transgenic plants were labelled with $\mathrm{Cy} 3$ and Cy5. A dye swop was included to minimize the effects of dye-specific labelling. An internal standard generated by pooling equal amounts of proteins from each sample was labelled with Cy2. Differentially labelled samples were immediately combined in a 1:1:1 ratio; rehydration buffer (7 M urea, $2 \mathrm{M}$ thiourea, $4 \% \mathrm{w} / \mathrm{v}$ CHAPS, $0.005 \%$ bromphenol blue) containing $60 \mathrm{mM}$ DTT and 2\% IPG buffer (GE Healthcare) was added to make up the volume to $150 \mu \mathrm{l}$. Thereafter, the samples were subjected to protein separation by two-dimensional PAGE.

\section{2-D gel electrophoresis}

After overnight rehydratation of the Immobiline dry strips (NL, pH 3-10; GE Healthcare) with Destreak, pooled labelled protein samples were separated on an IPGPhor Unit (GE Healthcare) using the following settings: 1 h $250 \mathrm{~V}$ (step), $7 \mathrm{~h} \mathrm{1,000} \mathrm{V} \mathrm{(gradient),} 3$ h 8,000 $\mathrm{V}$ (step), $3 \mathrm{~h} 45 \mathrm{~min} 8,000 \mathrm{~V}$ (gradient) for a total of $49.2 \mathrm{kVh}\left(50 \mu \mathrm{A} /\right.$ strip, $\left.20^{\circ} \mathrm{C}\right)$. After IEF, the strips were equilibrated for $15 \mathrm{~min}$ in equilibration buffer $(50 \mathrm{mM}$ Tris $/ \mathrm{HCl}, \mathrm{pH} 8.8,6 \mathrm{M}$ urea, $30 \% \mathrm{v} / \mathrm{v}$ glycerol, $2 \% \mathrm{w} / \mathrm{v}$ SDS, $0.01 \% \mathrm{w} / \mathrm{v}$ bromphenol blue) containing $0.1 \%$ dithriotreitol (DTT) and for 15 min in equilibration buffer containing $4.25 \%$ iodoacetamide. After rinsing the strips with water, they were mounted on top of a $12.5 \%$ SDS-polyacrylamide gel and overlaid with agarose sealing solution. SDS-PAGE was carried out in an EttanDALTsix unit (GE Healthcare) $(1 \mathrm{~h}$ at $0.1 \mathrm{~W} /$ gel, followed by $17 \mathrm{~h}$ at $1 \mathrm{~W} /$ gel).

\section{Gel imaging and data analysis}

Proteins were visualized by scanning using an Ettan DIGE Imager (GE Healthcare). All gels were scanned at $100 \mu \mathrm{m}$ (pixel size) resolution. The scanned gels were then directly transferred to the ImageQuant V5.2 software package (GE Healthcare) and saved as gel format. Gel images were cropped using the ImageQuant TL software programme (GE Healthcare) and gel analysis was carried out with the DeCyder 6.5 software (GE Healthcare). Spot detection was performed using the DIA (differential in-gel analysis) module with an estimated number of spots set to 10,000. After matching the gels using three landmarks, DIGE images were further analysed using the DeCyder BVA (biological variation analysis) module. For each transgenic and wildtype line, images from at least three biological repeats were used for the statistical analysis of protein abundance. A student's t-test in combination with correction for the false discovery rate was performed to identify spots of interest $(n=3, p<0.05)$. The differently expressed proteins were manually picked after staining the gels using silver staining (described in section 2.4).

\subsection{Quantitative RT-PCR}

Leaf samples (third leaf larger than $5 \mathrm{~cm}$ ) were taken from 15 separate plants of each of the two transgenic lines and the two wild-types at the same time in the morning and snap frozen in liquid nitrogen before storage at $-70^{\circ} \mathrm{C}$. RNA isolation, cDNA synthesis, primer design, and real-time PCR were performed, as described by Cortleven et al. [32]. Primer pairs of reference genes and genes of interest are listed in Table 3. Statistical

Table 3 Primer sequences of the used reference genes and genes of interest

\begin{tabular}{|c|c|c|c|}
\hline Genes & Accession Number & Primer sequence $5^{\prime}-3^{\prime}$ Primer sequence $3^{\prime}-5^{\prime}$ & Primer efficiency \\
\hline \multicolumn{4}{|c|}{ Reference genes } \\
\hline \multicolumn{4}{|c|}{ Nuclear-encoded } \\
\hline ACT9 & X69885 & $\begin{array}{l}\text { CTATTCTCCGCTITGGACTTGGCA } \\
\text { AGGACCTCAGGACAACGGAAACG }\end{array}$ & $95.67 \%$ \\
\hline$\alpha T U B$ & AJ421412.1 & $\begin{array}{l}\text { GATGTTGTGCCAAAGGATGTCA } \\
\text { GGCTGATAGTTGATACCACACTTGAAT }\end{array}$ & $93.43 \%$ \\
\hline SSU & X02353 & $\begin{array}{l}\text { AATGGATGGGTTCCTTGTTT } \\
\text { GTATGCCTTCTTCGCCTCTC }\end{array}$ & $107.16 \%$ \\
\hline \multicolumn{4}{|c|}{ Genes of interest } \\
\hline \multicolumn{4}{|c|}{ Nuclear-encoded } \\
\hline PSBO & AY220076 & $\begin{array}{l}\text { CGTGTGCCCTTCCTCTTCA } \\
\text { GATCCACCCCGTCCCTIT }\end{array}$ & $114.10 \%$ \\
\hline PSBP & X55354.1 & $\begin{array}{l}\text { CATTGTCGCTATCACCCCTAC } \\
\text { ATACGGTITCCCTCCCACTT }\end{array}$ & $87.18 \%$ \\
\hline$P S B Q$ & AB188569.1 & $\begin{array}{l}\text { CGTCATCGGTCTTGTTGT } \\
\text { CAATCTCCTTGGCTGAATCCT }\end{array}$ & $94.26 \%$ \\
\hline FNR & Y14032 & $\begin{array}{l}\text { CACCAATGACAAAGGGGAAG } \\
\text { GAATGAACGGAAAGGAGCAA }\end{array}$ & $92.29 \%$ \\
\hline$S O D B$ & M55909.1 & $\begin{array}{l}\text { CCCAACGGAGGAGGAGAG } \\
\text { GGAGTTTCACCAAGGCAAG }\end{array}$ & $90.67 \%$ \\
\hline
\end{tabular}


analysis was performed using SAS v. 9.1.3. by a student's $\mathrm{t}$-test. The normality and homogeneity of variance were tested using the Shapiro-Wilk and Levene tests [55]. In order to meet the assumptions, datasets were transformed using log transformation.

\section{Additional material}

Additional file 1: Table S1. Proteins from the second dimension (BN/SDS-PAGE) identified by MALDI-TOF/TOF. Include additional info from the identified proteins from the second dimension (BN/SDS-PAGE) such as accession number, p-value, protein score, peptide count, sequence coverage, sequence, ion score, observed precursor mass, mass error and identification method.

Additional file 2: Table S2. Proteins from stroma fraction (IEF/SDSPAGE) identified by MALDI-TOF/TOF. Include additional info from the identified proteins from the stroma fraction (IEF/SDS-PAGE) such as accession number, $\mathrm{p}$-value, protein score, peptide count, sequence coverage, sequence, ion score, observed precursor mass, mass error and identification method.

\section{Abbreviations}

ACC-synthase: 1-aminocyclopropane-1-carboxylic acid synthase; ATP: adenosine-5'-triphosphate; BN: blue-native; CaMV 35S: cauliflower mosaic virus 355 promoter; CDNA: complementary DNA; CF1: hydrophylic headpiece ATP synthase; CKX: gene encoding cytokinin oxidase; ClpA: Caseinolytic protease A; FAD: flavine-adenine-dinucleotide; FNR: ferredoxin-NADP ${ }^{+}$-reductase; GTP: guanosine triphosphate, IPT: gene encoding adenosine phosphate-isopentenyl transferase; LHC: light-harvesting complex; NADP: nicotinamide-adenine dinucleotidephosphate,NtACC: Nicotiana tabacum gene encoding $\beta$ subunit of acetyl-CoA carboxylase; NtACT9: Nicotiana tabacum gene encoding actin 9; NtATPC: Nicotiana tabacum gene encoding gamma subunit of ATP synthase; NtaTUB: Nicotiana tabacum gene encoding alfa-tubulin; NtFNR: Nicotiana tabacum gene encoding ferredoxin-NADPreductase; NtIN1: Nicotiana tabacum gene encoding initiation factor 1; NtNDHI: Nicotiana tabacum gene encoding NADH dehydrogenase subunit; NTPETD: Nicotiana tabacum gene encoding subunit IV of cytochrome $b_{6} f_{i}$ NtPSAA:Nicotiana tabacum gene encoding PSI-A; NtPSAB: Nicotiana tabacum gene encoding PSI-B; NtPSBC: Nicotiana tabacum gene encoding PSII CP43; NtPSBD: Nicotiana tabacum gene encoding D1; NtPSBE: Nicotiana tabacum gene encoding cytochrome b559; NtPSBO: Nicotiana tabacum gene encoding 33 kDa of oxygen evolving complex; NtPSBP: Nicotiana tabacum gene encoding $23 \mathrm{kDa}$ of oxygen evolving complex; NtPSBQ: Nicotiana tabacum gene encoding $17 \mathrm{kDa}$ of oxygen evolving complex; NtRBCL: Nicotiana tabacum gene encoding large subunit of RubisCO; NtRBCS: Nicotiana tabacum gene encoding small subunit of RubisCO; NtRPS3: Nicotiana tabacum gene encoding ribosomal protein S3; NtSOD: Nicotiana tabacum gene encoding superoxide Fe dismutase; NISSU: Nicotiana tabacum gene encoding small subunit of RubisCO; OEC: oxygen evolving complex; PSI: photosystem I; PSII: photosystem II; Pssu: promotor small subunit RubisCO; RNA: ribonucleic acid; ROS: reactive oxygen species; Rubisco: ribulose-1,5-bisphosphate Carboxylase/Oxygenase; SOD: superoxide dismutase.

\section{Acknowledgements}

Anne Cortleven was aspirant for the Scientific Research-Foundation Flanders (FWO). Technical assistance of Greet Clerx and Jan Daenen is greatly acknowledged. We also thank Erik Royackers for help with the identification of the first dimension BN-PAGE. Special thank to Prof. dr. Yves Guisez and Ing. Stefaan Vandamme http://www.ceproma.ua.ac.be for the assistance with the MALDI-TOF/TOF analysis. We also want to thank Tomáš Werner for critical reading of the manuscript.

\section{Author details}

'Laboratory of Molecular and Physical Plant Physiology, Faculty of Sciences, Hasselt University, Diepenbeek, Belgium. ${ }^{2}$ School of Life Sciences, Biomedical
Research Institute and Transnational University Limburg, Hasselt University, Diepenbeek, Belgium.

\section{Authors' contributions}

AC participated in design of the study, performed all the experimental procedures and drafted the manuscript. JPN participated in the identification of the proteins by MALDI/TOF(TOF). RV conceived of the study, participated in its design and helped to draft the manuscript. All authors read and approved the final manuscript.

\section{Competing interests}

The authors declare that they have no competing interests.

Received: 14 December 2010 Accepted: 26 June 2011 Published: 26 June 2011

\section{References}

1. Mok MC: Cytokinins and plant development.Edited by: Mok DWS, Mok MC. Cytokinins: Chemistry, Activity and Function, CRC Press; 1994:57-79.

2. Werner T, Schmülling T: Cytokinin action in plant development. Curr Opin Plant Biol 2009, 12:527-538.

3. Sakakibara H: Cytokinins: activity, biosynthesis and translocation. Annu Rev Biol 2006, 57:431-449.

4. Müller B, Sheen J: Arabidopsis cytokinin signalling pathway. STKE 2007, $407 / \mathrm{cm} 5$.

5. Argueso $C T$, Ferreira FJ, Kieber JJ: Environmental perception avenues: the interaction of cytokinin and environmental response pathways. Plant Cell Environ 2009, 32:1147-1160.

6. Mothes K: Uber das Altern der Blätter und die Möglichkeit ihrer Wiederverjüngung. Die Naturwissenschaft 1960, 47:337-351.

7. Stetler DA, Laetsch WM: Kinetin-induced chloroplast maturation in cultures of tobacco tissue. Science 1965, 17:1387-1388.

8. Parthier B: The role of phytohormones (cytokinin) in chloroplasts development. Biochem Physiol Pflanzen 1997, 174:173-214.

9. Synková H, Schnablová R, Polanská L. Husák M, Siffel P, Vácha F, Malbeck 」, Machácková I, Nebesárová J: Three-dimensional reconstruction of anomalous chloroplasts in transgenic ipt tobacco. Planta 2006, 223:659-671.

10. Miyazawa Y, Kato H, Muranaka T, Yoshida S: Amyloplast formation in cultured tobacco BY-2 cells requires a high cytokinin content. Plant Cell Physiol 2002, 43:1534-1541.

11. Chernyad'ev II: Ontogenetic Changes in the Photosynthetic Apparatus and Effects of Cytokinins (Review). Applied Biochemistry and Microbiology 2010, 36:527-539.

12. Catský J, Pospišilová J, Macháčková I, Wilhelmová N, Šesták Z: Photosynthesis and water relations in transgenic tobacco plants with TDNA carrying gene 4 for cytokinin synthesis. Biologia Plantarum 1993, 35:393-399.

13. Chory J, Reinecke D, Sim S, Washburn T, Brenner M: A role for cytokinins in de-etiolation in Arabidopsis. Plant Physiol 1994, 104:339-347.

14. Kusnetsov W, Oelmüller R, Sarwat MI, Porfirova SA, Cherepneva GC, Herrmann RG, Kulaeva ON: Cytokinin, abscisic acid and light affect accumulation of chloroplast proteins in Lupinus luteus cotyledons without notable effect on steady-state mRNA levels. Planta 1994, 194:318-327.

15. Kusnetsov W, Herrmann RG, Kulaeva ON, Oelmüller R: Cytokinin stimulates and abscisic acid inhibits greening of etiolated Lupinus luteus cotyledons by affecting the expression of the light-sensitive protochlorophyllide oxidoreductase. Mol Gen 1998, 25:21-28.

16. Yaronskaya R, Vershilovskaya I, Poers Y, Alawady AE, Averina N, Grimm B: Cytokinin effects on tetrapyrrole biosynthesis and photosynthetic activity in barley seedlings. Planta 2006, 224:700-709.

17. Okazaki K, Kabeya Y, Suzuki K, Mori T, Ichikawa T, Matsui M, Nakanishi H, Miyagishima SY: The PLASTID DIVISION1 and 2 components of the chloroplast division machinery determine the rate of chloroplast division in land plant cell differentiation. Plant Cell 2009, 21:1769-1780.

18. Benková E, Witters E, Van Dongen W, Kolár J, Motyka V, Brzobohatý B, Van Onckelen HA, Machácková I: Cytokinins in tobacco and wheat chloroplasts: occurrence and changes due to light/dark treatment. Plant Physiol 1991, 121:245-251.

19. Kasahara H, Takei K, Ueda N, Hishiyama S, Yamaya T, Kamiya Y, Yamaguchi S: Distinct isoprenoid origins of cis- and trans-zeatin biosynthesis in Arabidopsis. J Biol Chem 2004, 279:14049-14054. 
20. Hoth S, Ikeda Y, Morgante M, Wang X, Zuo J, Hanafey MK, Gaasterland T, Tingey SV, Chua NH: Monitoring genome-wide changes in gene expression in response to endogenous cytokinin reveals targets in Arabidopsis thaliana. FESB Lett 2003, 554:373-380.

21. Rashotte AM, Carson SD, To JP, Kieber JJ: Expression profiling of cytokinin action in Arabidopsis. Plant Physiol 2003, 132:1998-2011.

22. Brenner WG, Romanov GA, Köllmer I, Bürkle L, Schmülling T: Immediateearly and delayed cytokinin response genes of Arabidopsis thaliana identified by genome-wide expression profiling reveal novel cytokininsensitive processes and suggest cytokinin action through transcriptional cascades. Plant J 2005, 44:314-333.

23. Zubo YO, Selivankina SY, Yamburenko MV, Zubkova NK, Kulaeva ON, Kusnetsov W: Cytokinins Activate Transcription of Chloroplast Genes. Doklady Biochemistry and Biophysics 2005, 400:48-51.

24. Zubo YO, Yamburenko MV, Selivankina SY, Shakirova FM, Avalbaev AM, Kudryakova NV, Zubkova NK, Liere K, Kulaeva ON, Kusnetsov V, Börner T: Cytokinin stimulates chloroplast transcription in detached barley leaves. Plant Physiol 2008, 148:1082-1093.

25. Lochamnová G, Zdráhal Z, Konečná H, Koukalová S, Malbeck J, Souček P, Válková M, Kiran NS, Brzobohatý B: Cytokinin-induced photomorphogenesis in dark-grown Arabidopsis: a proteomic analysis. $J$ Exp Bot 2008, 59:3705-3719.

26. Cerný M, Dycka F, Bobál'ová J, Brzobohaty B: Early cytokinin response proteins and phosphoproteins of Arabidopsis thaliana identified by proteome and phosphoproteome profiling. J Exp Bot 2011, 62:921-937.

27. Van Loven K, Beinsberger SEl, Valcke RLM, Van Onckelen HA, Clijsters HMM: Morphometric analysis of the growth of Phsp70-ipt transgenic tobacco plants. J Exp Bot 1993, 44:1671-1678.

28. Gatz C: Novel inducible/repressible gene expression systems. Methods Cell Biol 1995, 50:411-424

29. Quanten L, Chaerle L, Noben JP, van Onckelen H, Prinsen E, Van Der Straeten D, Valcke R: Effects of tetracycline on wild-type and inducible P35So IPT-5/TETR transgenic tobacco plants. Physiol Plant 2007, 130:290-300.

30. Beinsberger SE, Clijsters HM, Valcke RL, Van Onckelen HA: Morphological characteristics and phytohormone content of ipt-transgenic tobacco. Edited by: Karssen CM, Van Loon LC, Vreugdenhil D. Progress in Plant Growth Regulation, Kluwer Academic Publishers, Dordrecht; 1992:738-745.

31. Werner T, Holst K, Pörs Y, Guivarc'h A, Mustroph A, Chriqui D, Grimm B, Schmülling T: Cytokinin defiency causes distinct changes of sink and source parameters in tobacco shoots and roots. J Exp Bot 2008, 59:2659-2672.

32. Cortleven A, Remans T, Brenner WG, Valcke R: Selection of plastid- and nuclear-encoded reference genes to study the effect of altered endogenous cytokinin content on photosynthesis genes in Nicotiana tabacum. Photosynthesis Research 2009, 102:21-29.

33. Synková H, Van Loven K, Pospišilová J, Valcke R: Photosynthesis of Transgenic Pssu-ipt Tobacco. J Plant Physiol 1999, 155:173-182.

34. Peltier JB, Friso G, Kalume DE, Roepstorff P, Nilsson F, Adamska I, van Wijk KJ: Proteomics of the chloroplast: systematic identification and targeting analysis of lumenal and peripheral thylakoid proteins. Plant Cell 2000, 12:319-341.

35. Whitelegge JP, Gomez SM, Faull KF: Proteomics of membrane proteins. Adv Protein Chem 2003, 65:271-307.

36. Santoni $V$, Molloy M, Rabilloud T: Membrane proteins and proteomics: un amour impossible? Electrophoresis 2000, 21:1054-1070.

37. Eubel H, Braun HP, Millar AH: Blue-native PAGE in plants: a tool in analysis of protein-protein interactions. Plant Methods 2005, 1:1-11.

38. Werner T, Motyka V, Strnad M, Schmülling T: Regulation of plant growth by cytokinin. Plant Biol 2001, 98:10487-10492.

39. Werner T, Motyka V, Laucou V, Smets R, Van Onckelen H, Schmülling T: Cytokinin-deficient transgenic Arabidopsis plants show multiple developmental alterations indicating opposite functions of cytokinins in the regulation of shoot and root meristem activity. Plant Cell 2003, 15:2532-2550

40. Heinemeyer J, Eubel H, Wehmhöner D, Jänsch L, Braun HP: Proteomic approach to characterize the supramolecular organization of photosystems in higher plants. Phytochemistry 2004, 65:1683-1692.

41. Aro EM, Suorsa M, Rokka A, Allahverdiyeva Y, Paakkarinene V, Saleem A, Battchikova N, Rintamäki E: Dynamics of photosystem II: a proteomic approach to thylakoid protein complexes. J Exp Bot 2005, 56:347-356.
42. Timperio AM, D'Amici GM, Barta C, Loreto F, Zolla L: Proteomic, pigment composition, and organization of thylakoid membranes in iron-deficient spinach leaves. J Exp Bot 2007, 58:3695-3710.

43. Sanis JK, Dani DN, Dey GK: Involvement of thylakoïd membranes in supramolecular organisation of Calvin cyle enzymes in Anacystis nidulans. Plant Physiol 2003, 160:23-32

44. Van Camp W, Inzé D, Van Montagu M: The regulation and function of tobacco superoxide dismutases. Free Radical Biology and Medicine 1997, 23:515-520.

45. Synková H, Semorádová Š, Schnablová R, Witters E, Hŭsák M, Vacke R: Cytokinin-induced activity of antioxidant enzymes in transgenic Pssu-ipt tobacco during plant ontogeny. Biologia Plant 2006, 50:31-41.

46. Rodriguez RE, Modeyro A, Poli HO, Zurbriggen M, Peisker M, Palatnik JF, Tognetti VB, Tschiersch H, Hajirezaei MR, Valle EM, Carrillo N: Transgenic tobacco plants overexpressing chloroplastic ferredoxin-NADP(H) reductase display normal rates of photosynthesis and increased tolerance to oxidative stress. Plant Phys 2007, 143:639-649.

47. Gottesman S, Squire C, Pichersky E, Carrington M, Hobbs M, Mattick JS, Darlymple B, Kuramitsu H, Shiroza T, Foster T, Clark WP, Ross B, Squires CL, Maurizi MR: Conservation of the regulatory subunit for the Clp ATPdependent protease in prokaryotes and eukaryotes. Proc Nat AC Sci USA 1990, 87:3513-3517.

48. Zheng B, Macdonald TM, Sutinen S, Hurry V, Clarke AK: A nuclear-encoded ClpP subunit of chloroplast ATP-dependent Clp protease is essential for early development in Arabidopsis thaliana. Planta 2006, 224:1103-1115.

49. Sakamoto W: Protein degradation machineries in plastids. Annu Rev Plant Phys 2006, 57:599-621

50. Kleffmann T, van Zychlinski A, Russenberger D, Hirsch-Hoffmann M, Gehrig P, Gruissem W, Baginsky : Proteome dynamics during plastid differentiation in rice. Plant Physiol 2007, 143:912-923.

51. Gygi SP, Rochon Y, Franza R, Aebersold : Correlation between protein and mRNA abundance in yeast. Mol Cell Biol 1999, 19:1720-1730.

52. Beck FC: Signaling pathways from the chloroplast to the nucleus. Planta 2005, 222:743-756.

53. Bartlett SG, Grossman AR, Chua N-H: In vitro synthesis and uptake of cytoplasmatically-synthesized chloroplast proteins.Edited by: Edelman et al. Methods in Chloroplast Molecular Biology, Elsevier/North Holland; 1982:1081-109.

54. Reisinger V, Eichacker LA: Analysis of Membrane Protein Complexes by Blue Native PAGE. Practical Proteomics 2006, 1-2:6-15.

55. Neter J, Kutner MH, Nachtsheim CJ, Wasserman W: Applied Linear Statistic models The McGraw-Hill Companies, Inc; 1996.

doi:10.1186/1477-5956-9-33

Cite this article as: Cortleven et al:: Analysis of the photosynthetic apparatus in transgenic tobacco plants with altered endogenous cytokinin content: a proteomic study. Proteome Science 2011 9:33.

\section{Submit your next manuscript to BioMed Central and take full advantage of:}

- Convenient online submission

- Thorough peer review

- No space constraints or color figure charges

- Immediate publication on acceptance

- Inclusion in PubMed, CAS, Scopus and Google Scholar

- Research which is freely available for redistribution

Submit your manuscript at www.biomedcentral.com/submit
C Biomed Central 